\title{
Draft Environmental Analysis (EA) for the Coriell Island Purchase
}

A Proposed Project for the Riparian/Wetland Conservation Program,

a Part of Region One's Wildlife Mitigation Program

for Hungry Horse Dam

December 19, 1995
STATE DOCUMENTS COLLECTION

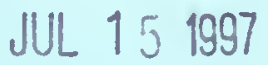

MONTANA STATE LIBRARY

1515 E. 6th AVE.

HELENA, MONTANA 59620
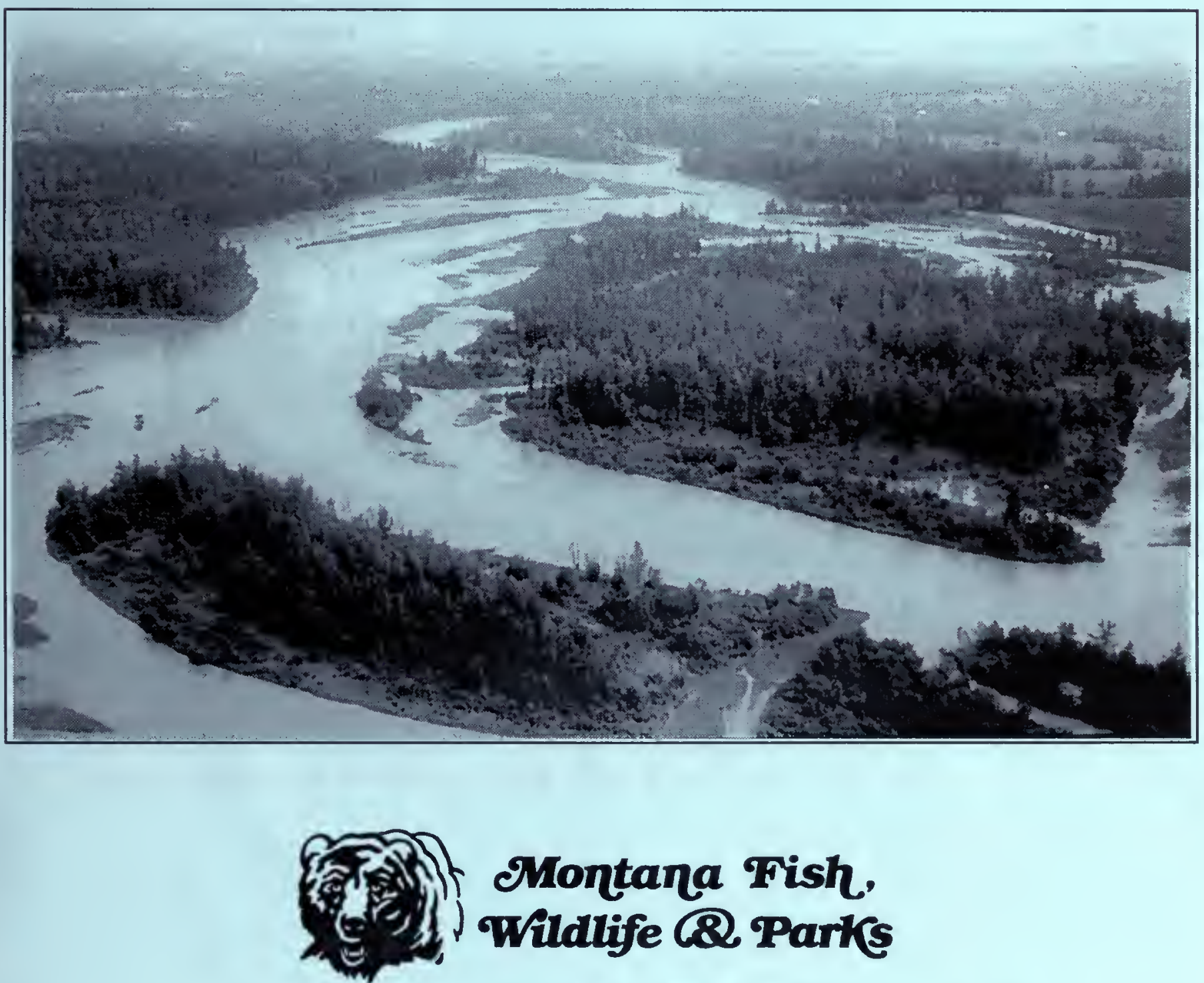

Montana Fish. Wildlife \& Parks

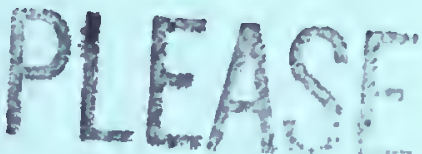


.

○

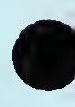

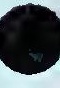




\section{oMontana Department \\ of \\ Fish,Wildlife \& Park's}

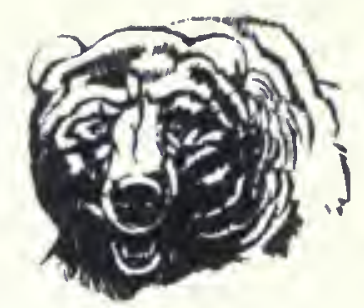

Region One

490 North Meridian Rd.

Kalispell, MT 59901

(406) 752-5501

FAX: 406-257-0349

Ref:DV190.96

December 19, 1995

Fish, Wildlife \& Parks Commissioners:

Stan Meyer, 3417 14th Ave. S., Great Falls, 59605

David W. Simpson, 844 W. Fifth St., Hardin, 59034

Darlyne Dascher, HC65, Box 25, Fort Peck, 59223

Charles R. Decker, CRD Timber \& Logging, 176 Hammer Rd., Libby, 59923

Dale R. Tash, 108 Tobacco Root Rd., Dillon, 59725

Montana Fish, Wildlife \& Parks

Director's Office

Parks Division

Fisheries Division

Wildlife Division

Regional Supervisors

Lands Section

Legal Unit

Environmental Quality Council, Capitol Building, Helena, 59620-1704

Dept. of Health \& Environmental Quality, Metcalf Bldg., PO Box 200901, Helena, 59620-0901

Montana Historical Society, State Historic Preservation Office, 225 North Roberts, Veteran's

Memorial Building, Helena, 59620-1201

Adjacent Landowners:

Flathead County Parks and Recreation, 225 Cemetery Rd. Kalispell, 59901

Flathead National Forest, 1935 3rd Avenue East, Kalispell, 59901

Montana Dept. of Natural Resources, 2250 Hwy 93 North, Kalispell, 59901-2557

Jane Holter, 760 Wishart Rd. Kalispell, 59901

Sherry and Laryssa Wilbert, 1200 Channel Dr. Missoula, 59901

Linda Pete, P.O. Box 1096, Ft. Washakie, WY. 82514

Van Kirke and Douglas Nelson, P.O. Box 1175, Kalispell, 59901

Patrick and Janette Oliver, 600 Ringneck Dr. Kalispell, 59901

Arnold B. and Carol Morris, 130 Shawnee Dr., Bigfork, 59911-6222

Ladies and Gentlemen:

The enclosed Environmental Assessment (EA) has been prepared for the proposed purchase of Coriell Island within the Flathead River near Kalispell, Montana, and is submitted for your consideration. Questions and comments will be accepted until January 22, 1995. There will be a public hearing at 7 p.m. on January 18, 1996 at the Outlaw Inn, Kalispell, MT. Please direct your questions or comments to Gael Bissell, FWP, at the above address. Thank you.

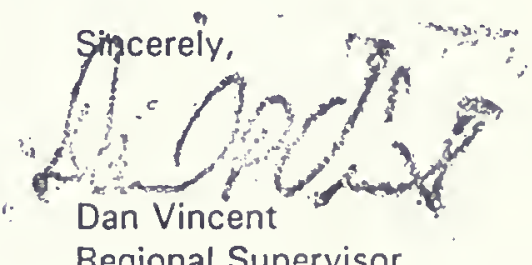

Regional Supervisor

Inb 
c: Montana State Library, 1515 East Sixth Avenue, Helena, 59620-1800

Wildlife Mitigation Advisory Council (attached)

Flathead County Commissioners, Flathead County Courthouse, Kalispell, 59901

Confederated Salish and Kootenai Tribes and Culture Committees

Francis Auld, Kootenai Culture Committee, Box 155, Elmo, 59915

Tony Incashola, Salish Culture Committee, Box 418, St. Ignatius, 59865

Mickey Pablo, Chairman, CSKT, PO Box 278, Pablo, 59855

Other Interest Groups:

Jim Jensen, Montana Environmental Information Center, PO Box 1184, Helena, 59624

George Ochenski, PO Box 689, Helena, 59624

Bob Cole, Flathead Wildlife Inc. P.O. Box 4, Kalispell, 59901

Walt Bahr, Flathead Land Trust, 403 Parkway Lane, Kalispell, 59901

Leo Keane, Flathead Audubon Society, 514 Pine Place, Whitefish, 59937 
DALE BECKER

CONF SALISH AND KOOTENAI TRIEES

BoX 278

ALAN CHRISTENSEN

USFS

PO BOX 7669

MISSOUTA MT 59806

BERNIE HALL

MONTANA NATURE CONSERVANCY

32 E EWING

HELENA MT 59620

LARRY LOCKARD

USFWS

780 CRESTON HATCHERY RD

KALISPELL MT 59901

WALT MOORE

WESTERN MT $G \& T$

PO $30 \times 4885$

MTSSOULA MT 59806
KEN BRUNNER

DEPT OF THE ARMY

PO BOX C - 3755

SEATTLE WA 98124

RICK CLARK
USBR
HUNGRY HORSE MT 59919

JOHN HINES

NORTHWEST POWER PLANNING COUNCIL CAPITOL STATION

HELENA MT 59605

DIANA MACDONALD

PACIFIC NW UTIL CONF COMM

101 SW MAIN ST 810

PORTLAND OR 97204

JERRY WELLS

MT FISH WILDLIFE AND PARKS

1420 EAST SIXTH AVE

HELENA MT 59620
DON CHILDRESS

MT FISH WILDLIFE AND PARKS

1420 EAST SIXTH AVE

HELENA MT 59620

HOWARD GIPE

FLATHEAD COUNTY COMMISSIONER

800 S MAIN

KALISPELL MT 59901

GAIL KUNT2

BONNEVILLE POWER ADMIN

100 NORTH PARK ST 330

HELENA MT 59601

WARREN MCCONKEY

FLATHEAD ELECTRIC COOP

2510 HWY 2 EAST

KALISPELL MT 59901

NOEL WILLIAMS

LINCOLN COUNTY COMMISSIONER

LINCOLN COUNTY COURTHOUSE

LIBBY MT 59923 
6

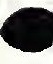

3 


\section{PART I. DESCRIPTION OF PROPOSED ACTION}

\section{A. PROPOSED ACTION}

The Montana Fish, Wildlife and Parks (FWP) is proposing to purchase approximately 73 acres of an island in the middle of the Flathead River just east of Kalispell, Montana (Section 22, Township 28 N, Range 21 W.) (Fig 1). The purchase would meet the goals of FWP's Riparian/Wetland Conservation Program, an element of the Regions's Wildlife Mitigation Program for Hungry Horse Dam, and utilize interest from the Wildlife Mitigation Trust Fund.

This property was donated to the Flathead Land Trust (FLT) on December, 1991, by Dr. Earl Coriell, of Polson Montana. FLT is a community-based, non-profit, taxexempt organization dedicated to protecting wildlife habitat, open-space, and traditional lifestyles in Flathead County. The FLT is not set up to own and manage lands; rather, FLT's focus is on public education, conservation easements, and facilitating land conservation for public interests. Revenue from this sale would facilitate FLT's conservation efforts.

The FLT is offering this tract to FWP as a bargain sale. FLT policy dictates that they cannot own land due to management costs and responsibilities. Because of the islands's outstanding natural and recreation values, FLT desires to transfer the property to public ownership.

\section{B. AUTHORITIES AND DIRECTION}

FWP is mandated by public law (87-1-201) to protect, enhance, and regulate the wise use of Montana's fish and wildlife resources for public benefit now and in the future. Recently, the FWP Commission adopted Habitat Montana policy and plan (FWP 1995a) which calls for FWP to focus conservation efforts on "intermountain grassland, shrub grassland, and riparian ecosystems".

In addition, the Northwest Power Act of 1980 (P.L. 96-501) authorized the creation of the Northwest Power Planning and Conservation Council (NPPC) and charged it with developing a program to "protect, mitigate and enhance fish and wildlife affected by the development, operation and management" of the federal hydropower system in the Columbia River Basin. Under the Northwest Power Act, the Bonneville Power Administration (BPA) and FWP established an agreement that provided funds from BPA for the protection, mitigation and enhancement of wildlife and wildlife habitat affected by the development of Libby and Hungry Horse Dams. This Settlement Agreement was signed in 1988; payments to the Wildlife Mitigation Trust Fund were completed in 1994. This preliminary project proposal was reviewed and unanimously approved by the Fish, Wildlife, and Parks Commission on August 3, 1995. The 
proposed action was also reviewed and unanimously supported by the Wildlife Mitigation Advisory Committee (WMAC) members on October 5, 1995. WMAC is the group established by the Settlement Agreement to provide recommendations and guidance to FWP on implementation of mitigation activities.

\section{PURPOSE AND NEED OF THE PROPOSED ACTION}

The primary purpose of this acquisition is to insure perpetual conservation of the riparian and wetland habitat resources of the island as a means to mitigate for some of the 6,978 acres of riparian and wetlands lost due to construction of Hungry Horse Dam. Because the Coriell island adjoins other public lands and is within a popular recreation corridor along the Flathead River mainstem, the project would result in the securing of public recreation values as well. The parcel would be managed as part of FWP's Wildlife Habitat Protection Area Program with primary management emphasis on habitat values and secondary focus on recreation values. A proposed management plan for the site is attached in Appendix A.

\section{PROPERTY DESCRIPTION}

The Coriell property occupies most of an island within the main channels of the Flathead River (Fig.1). The property is comprised of both riparian and wetland habitats in nearly pristine condition. The natural vegetation consists of mature cottonwoods, deciduous shrublands, and herbaceous communities typical of river systems. It is bisected by a primary river channel as well as other backwater channels. The island lies within an active or "delta" section of the Flathead River just upstream from its confluence with the Stillwater River. The island is within a highly dynamic area where the Flathead becomes a slow meandering river system (Fig. 2). This highly braided section exists because of the change in gradient between the upper and lower Flathead River systems which are influenced by Kerr dam which maintains higher than normal water levels in the Flathead River mainstem upstream from Flathead Lake during the summer months. This accentuates the delta-like depositional and erosional activity within this area.

The large number of islands and unpredictable river activity in this section has helped maintain the relatively undisturbed nature of this island. As a result, this braided section including Coriell island, supports some of the best and last examples of undisturbed mature and old growth riparian forest and high quality riparian habitats within the entire upper Flathead mainstem corridor.

The Coriell property occupies most of an entire island situated in the main channels of the Flathead River mainstem (Fig.1). FLT would deed to FWP all their rights, title and interests to the island the size of which may increase or decrease depending on river dynamics. 


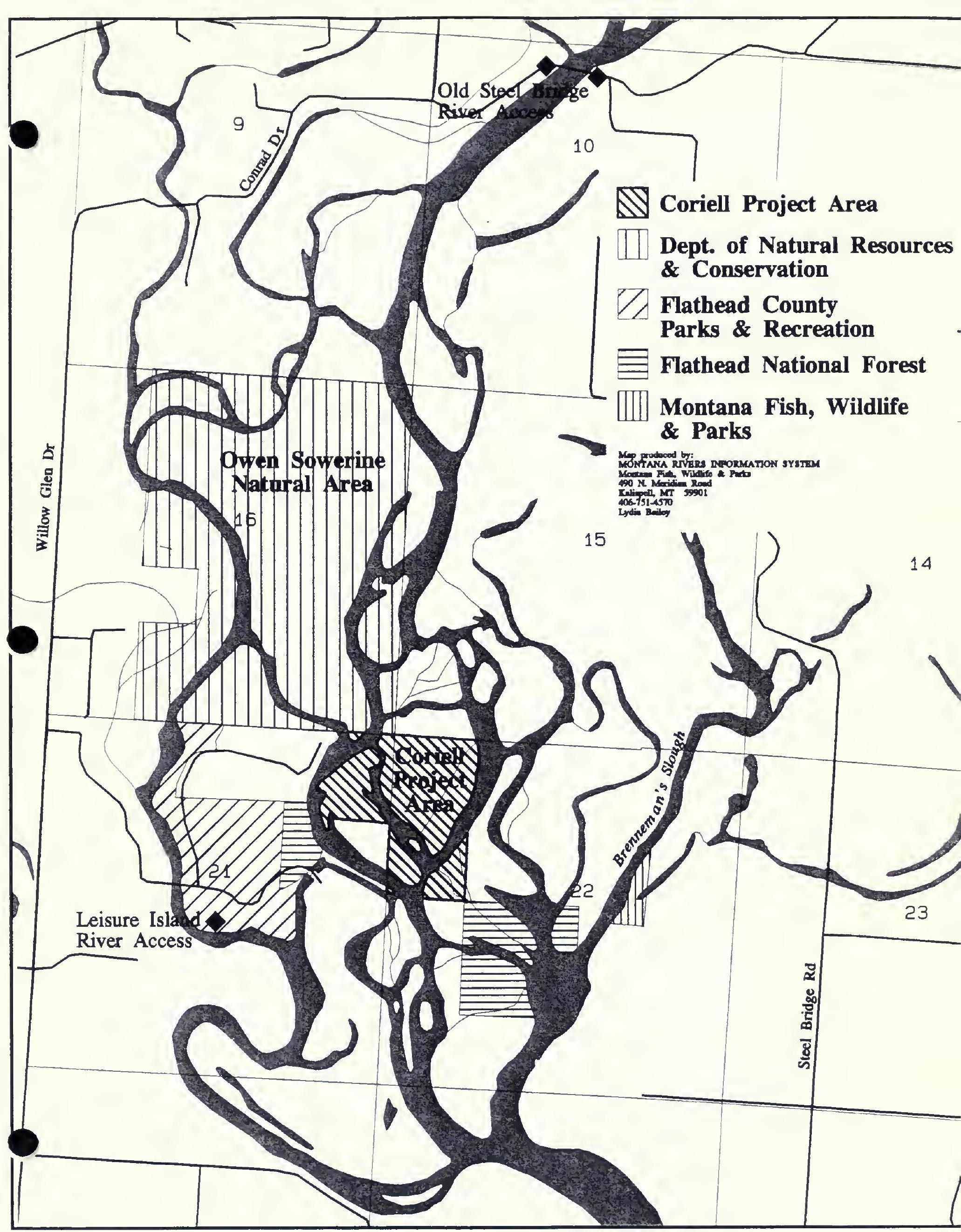

Figure 1. Location of Coriell proposed project area and adjacent public lands. 
The Flathead Forest owns a 40 acre tract of land and water to the southeast and approximately 10 acres to the southwest; however, the Flathead Forest is in the process of transferring all their Flathead River tracts to FWP. To the east of Coriell, along Brenneman's Slough, another 12 acres has been donated to FWP. The Department of State Lands leases approximately 442 acres northeast of Coriell to Flathead County with the lease expense paid by the Flathead Audubon Society. This tract, known as the Owen Sowerwine Natural Area, is the state's first and only designated natural area. Finally, Flathead County Parks and Recreation owns an undeveloped parcel directly to the west of Coriell (Fig. 1).

\section{E. VALUES OF PROPERTY}

\section{Wildlife}

The Coriell property provides year-round habitat for numerous game species including white-tailed deer, turkey, pheasants, ruffed grouse, a variety of waterfowl, beaver, river otter, mink, and muskrat. In fact, the proximity of this braided section to downstream sloughs, Brenneman's slough, the Stillwater River, and the island character make it some of the best river otter habitat in Montana. It is located within a river section which supports a high density of beaver ( 2 colonies per channel mile). It provides foraging habitat for great blue herons and double crested cormorants which have rookeries located just to the east of the island. It is used by osprey and bald eagles; active nests of these species occur nearby. It is also used by bald eagles wintering along the river. It provides excellent habitat for breeding and brood-rearing habitat for wood ducks, common and hooded mergansers, Barrows and common goldeneyes, Canada geese, and mallards. The island's wetland habitats support western toads and painted turtles. A wildlife species list based on surveys of the Owen Sowerwine Natural Area and adjacent habitats (Appendix A) is indicative of the wildlife diversity and importance of this habitat.

\section{Fisheries}

In addition to wildlife values, the aquatic habitat provides excellent foraging and cover habitat for a large number of migratory and resident fisheries. Most notable is the importance the Flathead mainstem for migratory adult and juvenile bull trout, a species warranted (but precluded) for listing as a threatened and endangered species by the U.S. Fish \& Wildlife Service, and west slope cutthroat trout, a species of special concern in Montana. Both these species use the gravel bars, overhanging banks, and channels for foraging and cover during their migrations.

\section{Recreation}


The island has traditionally been used for fishing, picnicking, bird watching, deer and waterfowl hunting. At present, the FLT has not posted the land. Duck blinds and deer stands indicate the island is still used for these activities.

\section{Mitigation Credit}

Fee-title acquisition of this property would result in 73 acres of mitigation credit for riparian/wetlands according to crediting policies described in FWP's Final Programmatic EIS on the Riparian/Wetland Conservation Program (FWP 1995b).

\section{F. THREATS}

There is little threat of subdivision or other incompatible land uses to the Coriell property at present. However, if FWP did not purchase Coriell, the FLT would sell the property to someone else. They may or may not place a conservation easement on the property prior to sale, thus wildlife, habitat and recreation values may not be guaranteed.

\section{G. MANAGEMENT GOALS AND OBJECTIVES}

The draft management plan (Appendix B) for Coriell Island calls for inclusion of this parcel in the FWP's Wildlife Division Wildlife Habitat Protection Area program. Wildlife Habitat Protection Areas are small parcels of land, often donated to FWP, with exemplary or special wildlife values. They are managed primarily for their wildlife habitat values and only secondarily for their recreation values. The island may also meet the criteria of the State Natural Areas Program. The potential for including the Coriell property inclusion into the Natural Areas Program, particularly with the Owen Sowerwine Natural Area located just northeast of Coriell, would be evaluated during implementation of this management plan.

As stated in the Draft Management Plan (Appendix B), the management goal for Coriell is: " to protect and maintain the riparian/wetland values and special wildlife uses associated with this island property and to allow recreation uses which do not undermine or impact these natural values".

\section{DESCRIPTION OF REASONABLE ALTERNATIVES}

\section{A. ALTERNATIVE 1. PURCHASE A CONSERVATION EASEMENT:}

FLT has not offered to sell a conservation easement to FWP. However, if FWP could purchase a conservation easement, this would ensure protection of the property's wildlife and habitat values equivalent to the proposed action (fee-title purchase). The 
value of the conservation easement, if recreation values were transferred would likely exceed the existing purchase price because recreation is the most marketable aspect of the property. If we were to purchase a conservation easement that did not include recreation rights, the value of the conservation easement would likely be less than the $\$ 22,000$ purchase price. However, under this option, public recreation opportunities could be limited or lost entirely. Given the relatively small purchase price for the land, it does not appear to be cost-effective to purchase a conservation easement. In general, conservation easement monitoring costs would be less than management costs.

\section{B. ALTERNATIVE 2. NO ACTION ALTERNATIVE:}

If FWP does not purchase the Coriell tract, FLT has indicated they would first try to sell it to someone else in fee-simple. Although we would expect FLT to sell to someone who would maintain the island's natural values, there would be no guarantee that this would occur, particularly in the future as population pressures continue to increase. Further, the public recreational values which would exist if FWP purchased the island, would likely be lost if FLT sold to someone else.

Depending on the market, FLT may feel the need to place a conservation easement on the property to protect its natural values prior to selling. If FLT did place a conservation easement on the property, it would likely focus on protecting the natural resource values and be silent to public recreation. As for the proposed action, if FLT sells the property with the conservation easement on the private market, FLT would use the income for other conservation programs.

Under the No Action Alternative, FWP would loose the opportunity to utilize the Riparian/Wetland Conservation program to meet mitigation goals. FWP may also loose the opportunity to work with FLT on other riparian/wetland conservation projects.

If FLT decides to sell Coriell without a conservation easement, the habitat integrity may not be fully protected. Gravel and sand extraction, grazing, logging or other activities, although at present unlikely, may ultimately occur in the future. Further, FWP would loose the opportunity to protect the property for its wildlife and habitat values, the objective of the Riparian/Wetland Conservation Program. In addition, FWP would loose opportunity to provide the public recreation opportunities associated with the island. If FLT receives full market value for this tract, they would be able to undertake more conservation elsewhere in the county.

\section{DESCRIPTION OF ALTERNATIVES CONSIDERED AND DISMISSED}

1. WAIT UNTIL FLT SELLS PROPERTY AND THEN MAKE OFFER TO PURCHASE CONSERVATION EASEMENT: 
This alternative would probably cost FWP more than the existing offer of $\$ 22,000$ which includes all interest in the land. In addition, there is no guarantee that the new landowner would be interested in working with FWP.

2. PURCHASE A CONSERVATION EASEMENT FOR BOTH HABITAT VALUES AND RECREATION FROM FLT:

This alternative is essentially offering to purchase most of all rights currently associated with this tract but not be responsible for its management. FLT board has adopted a policy which stipulates they do not want to be landowners or land managers. With a highly restrictive conservation easement attached to Coriell, FLT may not be able to market the property and would incur management costs. Cost of a restrictive conservation easement may be more than the current bargain sale price for fee-title to FWP.

3. LEASE:

FLT has had a policy that they do not intend to be long-term land owners or managers; a lease would still require them to obtain liability insurance and manage the lease. This is not an option for FLT at this point in time.

\section{PART III ENVIRONMENTAL REVIEW}

\section{A. EVALUATION OF THE PROPOSED ACTION AND REASONABLE ALTERNATIVES ON THE PHYSICAL ENVIRONMENT}

\section{Land Resources:}

Proposed Action: The proposed action would result in long-term protection of land resources such as topsoil, wetlands, gravel bars, and sandbars. Land uses which might negatively impact land resources such as sand and gravel mining would be precluded under FWP ownership.

Alternative 1 (Purchase Conservation Easement): This alternative would result in the same benefits to land resources as the proposed action.

No Action: This Alternative could result in the potential loss of the values associated with land resources because there would be no guarantee that these resources would be protected by the next landowner. Impacts could include sand and gravel removal, cottonwood logging, local disturbances related to 
construction of cabin or shelter, and soil erosion and fertility impacts should domestic livestock grazing be introduced. ${ }^{1}$

\section{Air Resources:}

Proposed Action: No impact expected.

Alternative 1 (Purchase Conservation Easement): No impact expected.

No Action: No impact expected.

\section{Water Resources:}

Proposed Action: The Proposed Action will result in long-term protection of Flathead River surface and ground water quality through the protection of stream banks, river channels, backwater areas, and land resources.

Alternative 1 (Purchase Conservation Easement): This Alternative will result in the same benefits listed for the Proposed Action.

No Action: Although unlikely to occur in the near future, sand or gravel excavation, cottonwood logging, domestic livestock grazing, or shelter/cabin construction activities may have negative potentially significant impacts to water quality.

\section{Vegetation Resources:}

Proposed Action: The proposed action should provide long-term protection for native riparian and wetland plant communities. Native plant communities include cottonwood forest, riparian shrublands (willow, red-osier dogwood, hawthorn, snowberry), and herbaceous communities (various sedges, bluejoint, cattail, cow parsnip, etc.) The existing infestation of Canada thistle poses a unique management problem as mechanical means of eradication would be difficult, chemical means could pose environmental risks, and biological control could be ineffective in areas subject to annual flooding. A suitable and safe means of Canada thistle management (as well as other noxious weeds should they become established) will be part of FWP's management

${ }^{1}$ Grazing is unlikely at present because the island is surrounding by major river channels; however, in time, channel shifts may put the river on one side or the other of the island thereby providing the future opportunity for someone to move livestock to the island. 
responsibility. Noxious weed management is addressed in the draft management plan. (Appendix B).

Alternative 1 (Purchase Conservation Easement): This alternative should result in the same benefits listed under the Proposed Action.

No Action: This Alternative may lead to degradation of vegetation resources through changes in land use such as sand and gravel mining, tree removal, construction of shelters or cabins, or grazing activities. Weed management would be the responsibility of the next landowner.

\section{Fish/Wildlife Resources:}

Proposed Action: The Proposed Action will result in long-term maintenance of existing important aquatic plant and invertebrates communities which, in turn, provide food and cover for a variety of fish and other aquatic mammals which utilize these habitats. Fish species which would benefit from long-term habitat protection include migratory juvenile and adult bull trout, west-slope cutthroat trout, and mountain white-fish. Other resident native fish which use the Flathead mainstem and braided section include squaw fish, peamouth, and large-scale sucker. Nonnative fish species such as rainbow trout, lake trout, Lake Superior whitefish, and kokanee salmon would also utilize the gravel bars, backwater and main channels of the Flathead River around this island. Maintenance of existing vegetation provides bank stability, shade and cover as well as future vegetative and organic material which provides nutrients, cover, and substrate for aquatic plant and animal communities.

The river and backwater channels would continue to provide breeding and foraging habitat for western toads and painted turtles while the riparian vegetation would continue to support a number common snakes such as common and western garter snakes. The proposed project would maintain foraging and/or breeding habitats for great blue herons, double crested cormorants, osprey, and bald eagles as well as woodpeckers, chickadees and other year-round resident birds (Appendix A). The vegetation would also continue to provide nesting and migratory habitat for a variety of neo-tropical migrants such as warblers, swallows, vireos, and thrushes.

In addition, the Proposed Action would continue to maintain year-round habitat for a number of important game species such as white-tailed deer, wild turkey, pheasants, ruffed grouse, canada geese, mallards and wood ducks, and a variety of other waterfowl. The aquatic and riparian habitats would continue to support beaver, river otter, mink, muskrat, raccoon, red fox, coyote, and striped skunks. 
Alternative 1 (Purchase Conservation Easement): This Alternative should result in the same benefits listed under the Proposed Action.

No Action: This Alternative offers nơ guarantee as to the continued maintenance of natural habitats and the species which depend on them. Future land uses such as sand and gravel operations, cottonwood logging, or grazing could have a detrimental impact on these resources.

6. Unique, endangered, fragile, or limited environmental resources:

Proposed Action: Extensive riparian areas in nearly pristine condition are relatively rare in Montana. The braided section near Kalispell has many of these qualities and this project would help to sustain this ecosystem. The project would also benefit breeding, wintering, and migrating bald eagles, a federally threatened species. It benefits river otter, osprey, and great blue herons, also species of special interest in Montana (Flath 1991). In addition, the project would benefit bull trout, a species warranting listing as a federal threatened or endangered species, and west-slope cutthroat trout, a fish species of special concern in Montana (Flath 1991).

Alternative 1 (Purchase Conservation Easement): Same as Proposed Action.

No Action: The opportunity to protect a biologically important, relatively rare and unique riparian/wetland community would be foregone.

B. EVALUATION OF THE PROPOSED ACTION AND REASONABLE ALTERNATIVES ON THE HUMAN ENVIRONMENT

1. Noise/Electrical Effects/Transportation

Proposed Action: Noise from hunting would probably be similar to that which exists today. No other noise effects expected. No impacts on electricity supply or demand or transportation are expected.

Alternative 1 (Conservation Easement): May be same as proposed action.

No Action: Noise from hunting would be the same as Alternative 1. There is a low probability that activities such as sand and gravel extraction or logging might occur at some point in the future. If these activities did occur, they would contribute to noise impacts in a natural setting and relatively quiet area. No impact to electrical or transportation effects are expected.

2. Public or Government Services/Schools/Utilities 
Proposed Action: The Proposed Action should result in no impact on public services or utilities. The proposed action will have no impact on local schools and should not require any other government services (outside of FWP) except during the development of a weed management plan. The proposed project will result in increased management responsibility for FWP; this could be translated into service contracts or employment. The costs may be shared between the Riparian/Wetland Conservation Program and FWP wildlife management area programs.

Alternative 1 (Conservation Easement): Most of the impacts would be the same as the Proposed Action. There would be no expected impact to government services, schools, or public utilities. The management costs for FWP may be less under a conservation easement which requires annual monitoring and coordination with the landowner than with purchase which requires design and implementation of management plans.

No Action: Minimal impacts expected to government services, schools, or public utilities due to low probability of development occurring within the main channel of the Flathead River.

\section{Existing and Future Land Uses/ Industrial \& Agricultural Production/}

\section{Housing}

Proposed Action: No impact to existing land uses expected as existing low intensity recreational land uses would not change. Because of its current location in the middle of the Flathead mainstem, the site is not generally suited for agricultural crops, industrial (other than sand and gravel), residential, or commercial activities (other than recreation based). Industrial activities such as sand and gravel operations or commercial activities such as private hunting preserve would be precluded by public ownership. Land use impacts associated with fee-title acquisitions under the Riparian/Wetland Conservation Program have also been disclosed in the Riparian/Wetland Programmatic EIS issued September 1995 by FWP.

Alternative 1 (Conservation Easement): Existing low intensity recreational land use would not change; however, it may be more limited and/or regulated depending on future landowner desires. Other extractive land uses such as sand and gravel, timber or agriculture would be precluded. This alternative would not preclude a private or commercial hunting preserve.

No Action: Although there is a low probability of residential, industrial, or commercial development occurring on an island in the main channel of the Flathead River, these land uses would not be precluded under the no action alternative. Potential land uses, although limited include sand and gravel 
operations, timber harvest, grazing, and commercial recreational uses such as a commercial hunting preserve.

\section{4. $\quad$ Risk/Health Hazards}

Proposed Action: No impact.

Alternative 1 (Conservation Easement): No impact.

No Action: Low probability of any type of risky or hazardous development occurring within the main channel of the Flathead River.

\section{Recreation/Local Economy/Aesthetics/Open Space}

Proposed Action: The impact of the proposed action will be to maintain high quality fish and wildlife habitat associated with the island. It will also help maintain the existing recreational opportunities associated with the Flathead River islands which, in turn, will maintain or encourage local river-related economies such as fishing, boating, bird-watching, and hunting. The proposed action will maintain existing open-space and aesthetics of the area. However, this alternative would not allow commercial development of these recreational opportunities (e.g. commercial hunting preserve). These general impacts have been described in the Riparian/Wetland Programmatic EIS issued September 1995 by FWP.

No additional impacts are expected to adjacent landowners as the island is already used by the public. The goals of the attached management plan are to first maintain the habitat values and secondarily to allow public use which does not impact wildlife or habitat values. Overnight camping and campfires would not be allowed. Monitoring public use and resulting impacts to the island and adjacent private land is an important element of the management plan.

Alternative 1 (Conservation Easement): Although the fish and wildlife habitat would be conserved, the actual opportunity for the public to recreate on the island would not be assured under this alternative. This recreational opportunity would likely be purchased by a future landowner for personal purposes or for profit.

No Action: Both the habitat base and public recreational opportunity which exists on the island would not be assured. When placed on the market, the Coriell property is likely to be purchased for personal recreational or habitat purposes or for profit from its recreational values (e.g. by an outfitter). Recreation, as the most marketable aspect of the property, would likely continue under all alternatives. However, the proposed action would allow 
public recreation while Alternative 1 and No Action could result in private recreation.

\section{Taxes, Financial, Employment Opportunities, Private Business}

Proposed Action: FLT is offering to sell their portion of the island to FWP for $\$ 22,000$ or approximately $\$ 301 /$ acre, a bargain sale price, well below the 1991 appraised value of $\$ 37,000$ or ( $\$ 507 /$ acre). Through market analysis completed by FLT, current value is estimated to range from $\$ 50,000-\$ 75,000$.

A Socio-Economic Assessment for the proposed action is attached (Appendix C). As discussed in this report, the Proposed Action will restore and maintain the tax proceeds to Flathead County as FWP is required to make Payments in Lieu of Taxes (PILT) to the county where they purchase land. Currently, no taxes are paid to the county due to FLT's tax exempt status. Although expected to be minimal, future taxes derived from extractive resources such as sand or gravel, timber, fish, wildlife, or vegetative resources may be foregone under the Proposed Action.

The maintenance of current habitat and recreation opportunity will help to maintain existing demand for outdoor recreation equipment and services.

Alternative 1 (Conservation Easement): Due to their tax exempt status, no property taxes would be derived for Flathead County if FLT retains ownership. No property taxes would be derived if the land were purchased by another tax-exempt organization. If FLT sells land to a private interest, the tax impacts would be the same as the Proposed Action with the exception that some potential business income and associated tax revenue which could be derived from private commercial hunting or fishing operations may occur.

No Action: The impacts would be similar to Alternative 1 with the addition that under the No Action Alternative, sand and gravel, logging, and grazing may occur at some point in the future.

\section{Cultural/Historic Resources}

Proposed Action: No expected impact. No permanent structures or vegetation or soil disturbance would occur under this alternative. The EA is currently being reviewed by the State Historic Preservation Office and the Confederated Salish and Kootenai Tribes culture committees to determine if any cultural or historic values exist within the proposed project area.

Alternative 1 (Conservation Easement): Same as Proposed Action. 
No Action: No immediate impact. Future impacts unknown at this time.

\section{Cumulative Effects}

Proposed Action: The Proposed Action may set a precedent for similar conservation projects along the Flathead River. It may encourage the donation or bargain sale of other island properties to FWP depending on the success of the management plan for Coriell and the impact, if any, on neighboring private lands. If FWP implemented additional riparian/wetland projects along the Flathead (conservation easement or purchases), FWP management responsibilities would increase and cause a need for additional service contracts or staff.

The proceeds of this sale would likely be used by FLT to further their conservation activities. The cumulative effects of these efforts should greatly benefit the physical and biological resources associated with the Flathead River mainstem. This would also benefit the recreational economy, aesthetics and open space needs. It would help encourage the existing rural lifestyle associated with the braided section.

The project fits in well with existing public ownership patterns and may provide for a variety of future management options.

Some of the commercial, agricultural, timber, or development rights associated with other lands being placed under a conservation easement could limit some potential future land uses along the river and resulting in lost future taxes to the local government.

Other socio-economic impacts of the Proposed Action are set forth in the Socio-Economic Assessment report attached to this EA (Appendix C). The cumulative impacts of the Riparian/Wetland Conservation Program were also disclosed in a Final Programmatic EIS issued in September, 1995 by FWP.

\section{Alternative 1 (Conservation Easement): Same as Proposed Action.}

No Action: If FWP does not purchase the Coriell property, the cumulative biological and socio-economic benefits may not be realized and the potential negative impacts may occur as described under the Proposed Action. On the other hand, if community interest in protecting the Flathead's natural resources continues (due to local efforts such as through the Flathead River Partnership and Flathead Land Trust) some of these cumulative effects of the Riparian/Wetland Conservation Program on the Flathead River may occur regardless of whether or not FWP purchases the Coriell property. Proceeds to FLT from the sale of this property to a private party would likely provide 
more money to conserve more habitat consistent with their program goals, than this sale to FWP.

\section{PART IV CONCLUSION SECTION}

1. Based on the significance criteria evaluated in this EA, is an EIS required?

The environmental impacts of this particular project are primarily positive; the project will result in benefits to physical and biological environment and will maintain existing land uses and recreational opportunities. The loss of future economic values are considered minimal and not significant when weighed against the impacts of these activities on this sensitive environment. The project is consistent with the goals, objectives, and strategies (number 2) of the Riparian/Wetland Conservation Program, an obligation FWP has to mitigate the effects of Hungry Horse Dam on wildlife habitat. The environmental effects of this Riparian/Wetland Conservation Program have been disclosed in both a Draft and Final EIS's.

2. Describe the level of public involvement for this project, if any, and given the complexity and the seriousness of the environmental issues associated with the Proposed Action, is the level of public involvement appropriate under the circumstances?

The Draft EA and notic of public comment period from December 19, 1995 to January 22,1996 will be sent to approximately 60 individuals, organizations, adjacent landowners, and required public agencies and offices. A notice of the Draft EA and 30-day public comment period will be sent to another 75 individuals or organizations within Flathead County which have participated in the Riparian/Wetland EIS process in the past. A news release and legal notice of EA availability and the dates of the formal public comment period will be sent to all regional daily and weekly newspapers. A public hearing is scheduled for Kalispell for January 18th. These actions should assure appropriate level of public review.

In addition, during development of both the Draft and Final Programmatic EIS's on the Riparian/Wetland Conservation Program, numerous public hearings and comment periods were held throughout northwest Montana (FWP 1995).

3. Duration of comment period for the Environmental Assessment:

December 23, 1995 - January 22, 1996

4. Other jurisdictional agencies/organizations:

The Flathead Regional Development Office and the Flathead County Commissioners have the primary jurisdictional oversight of land projects within Flathead County. 
They and other county, state, or federal agencies, public interest organizations, Confederated Salish and Kootenai tribes, and interested citizens will receive a notification or copy of the Draft and Final EA's as well as draft and final management plans. Adjoining private and public land owners such as the Flathead National Forest, Flathead County Parks and Recreation, and Department of State Lands (now Dept. of Natural Resources) will also be sent copies of the draft EA.

\section{Individuals/groups contributing to the EA?}

Dan Casey, Wildlife Biologist, FWP

Mike Conner, Executive Director, Flathead Land Trust

Mark Deleray, Fisheries Biologist, FWP

Darlene Edge, Land Agent, FWP

Brent Mitchell, Director, Flathead Audubon Society (Coordinator for Owen

Sowerwine Lease)

Alan Wood, Wildlife Mitigation Coordinator, FWP

6. Name, title, address and phone number of the persons(s) responsible for preparing the E.A.

Gael Bissell, Wildlife Biologist, Montana Fish, Wildlife, and Parks, 490 North Meridian Rd. Kalispell, MT. 59901; (406) 751-4580.

Alan Wood, Wildlife Mitigation Coordinator, Montana Fish, Wildlife and Parks, Flathead National Forest, 1935 3rd. Ave. East, Kalispell, MT 59901; (406) 758-5219. 


\section{REFERENCES CITED}

Flath D. 1991. Species of Special Interest or Concern. Montana Department of Fish, Wildlife and Parks. January 1991.

Montana Fish, Wildlife, and Parks 1995a. Statewide Habitat Plan, Implementation of Fish, Wildlife, and Parks Commission, Habitat Montana Policy, October 1995.

Montana Fish, Wildlife, and Parks 1995b. Final Programmatic Environmental Impact Statement on the Riparian/Wetland Habitat Conservation Program, Sept. 11, 1995. Montana Dep. Fish, Wildlife, and Parks, Kalispell, MT. 59901.

ref: coriell.gb 12/18/95 


\section{APPENDIX A}

\section{WILDLIFE SPECIES EXPECTED TO OCCUR ON CORIELL ISLAND BASED ON DATA COLLECTED AT THE OWEN SOWERWINE NATURAL AREA AND ADJOINING AREAS \\ (D. Casey, FWP, unpublished data).}

\section{Game Species}

White-tailed deer

Ring-necked pheasant

Ruffed grouse

Wild turkey

Morning dove

Canada goose

Furbearers

Beaver

Muskrat

River otter

Mink

Nongame Birds

Double-crested cormorant

Great-blue heron

Osprey

Bald eagle

Sharp-shinned hawk

Cooper's hawk

Red-tailed hawk

American kestrel

Killdeer

Spotted sandpiper

Ring-billed gull

Western screech owl

Great horned owl

Barred owl

Vaux's swift

Black-chinned hummingbird

Belted kingfisher

Downy woodpecker

Hairy woodpecker

Northern flicker

Pileated woodpecker

Western wood pewee

Willow flycatcher

Least flycatcher

Dusky flycatcher

Eastern kingbird

Tree swallow
Wood duck

Mallard

Common goldeneye

Bufflehead

Hooded merganser

Common merganser

Raccoon

Red fox

Coyote

Stripped skunk

Black-billed magpie

American crow

Black-capped chickadee

Red-breasted nuthatch

White-breasted nuthatch

House wren

Ruby-crowned kinglet

Veery

Swainson's thrush

American robin

Gray catbird

Cedar waxwing

European starling

Warbling vireo

Red-eyed vireo

Yellow warbler

American redstart

Northern waterthrush

MacGillivray's warbler

Common yellowthroat

Black-headed grosbeak

Lazuli bunting

Chipping sparrow

Song sparrow

Brewer's blackbird

Brown-headed cowbird

Northern oriole 
WILDLIFE SPECIES EXPECTED TO OCCUR ON CORIELL ISLAND BASED ON DATA COLLECTED AT THE OWEN SOWERWINE NATURAL AREA AND ADJOINING AREAS (Continued)

Nongame Birds

Violet-green swallow

House finch

Rough-winged swallow

Pine siskin

Bank swallow

Cliff swallow

American goldfinch

Barn swallow

House sparrow

Amphibians and Reptiles

Western toad

Painted turtle

Common garter snake

Western terrestrial garter snake

Rubber boa 


\title{
APPENDIX B
}

\section{CORIELL ISLAND DRAFT MANAGEMENT PLAN}

\author{
December 18, 1995
}

\section{PURPOSE}

The goal of this management plan is to describe how the $73+$ acre island, referred to as Coriell Island after Dr. Coriell from Polson, MT., will be managed by FWP, should this project be approved by the FWP Commission. The Coriell Management Plan describes the history and wildlife values of this island, outlines management goals and objectives, specifies various actions FWP plans to implement over the next 2 years, and gives interim guidance on public recreation management until more accurate data can be collected.

If the Coriell project is approved, the Montana Fish, Wildlife, and Parks (FWP) would include the Coriell Island into Wildlife Division's network of approximately 40 Wildlife Habitat Protection Areas (WHPA's) across the Montana. WHPA's are usually small parcels of land, often donated or sold to FWP below market value, which hold exemplary wildlife habitats or special wildlife use areas such as nesting islands. FWP manages several WHPA's in the Flathead basin including 2 islands within Flathead Lake.

The management philosophy behind the management of WHPA's is focused on protecting the wildlife habitat and special wildlife uses of the property. Recreation can occur on most WHPA's; however, only low impact types of uses are encouraged. Recreation is often discouraged during critical periods of wildlife use (e.g. during spring waterfowl nesting).

\section{MANAGEMENT GOALS}

The management goal for Coriell is: " to protect and maintain the riparian/wetland values and special wildlife uses associated with this island property and to allow recreation uses which do not undermine or impact these natural values".

There is a potential for including the Coriell property into the Montana Natural Areas Program. This potential will be evaluated during implementation of this management plan.

The Management Plan is organized by the following objectives: 1. Maintain Habitat Values; 2. Provide Public Recreational Opportunities; 3. Monitoring/Adaptive Management.

\section{PROPERTY DESCRIPTION}

The Coriell property occupies most of an island within the main channel of the Flathead River. The property is comprised of both riparian and wetland habitats in nearly pristine condition. The natural vegetation consists of mature cottonwoods, deciduous shrublands, and herbaceous communities typical of river systems. It is bisected by a primary river channel as well as other backwater channels. The island lies within an active or "delta" section of the Flathead River just upstream of its confluence with the Stillwater River at which point the Flathead mainstem becomes a slow meandering river. This highly braided section exists because of the change in gradient between the upper and lower Flathead River systems and 
the influence of Kerr dam which maintains higher than normal water levels in the Flathead River mainstem upstream from Flathead Lake during the summer months. This action accentuates the delta-like depositional and erosional activity within this area.

The large number of islands and unpredictable river activity in this section has helped maintain the relatively undisturbed nature of this island. As a result, this braided section including Coriell island, supports some of the best and last examples of undisturbed mature and old growth riparian forest and high quality riparian habitats within the entire upper Flathead mainstem corridor.

The 73 acre Coriell property occupies most of an island situated in the main channels of the Flathead River mainstem. The Flathead Forest owns 40 acres of land to the southeast and approximately 10 acres to the southwest; however, the Flathead Forest is in the process of transferring all their Flathead River tracts to FWP. To the east of Coriell, along Brenneman's Slough, another 12 acres has been donated to FWP. The Department of State Lands leases 442 acres northeast of Coriell to Flathead County Parks and Recreation with the lease expense paid by the Flathead Audubon Society. This tract, known as the Owen Sowerwine Natural Area, is the state's first and only designated natural area. Finally, Flathead County Parks and Recreation owns an undeveloped parcel directly to the west of Coriell.

\section{MANAGEMENT OBJECTIVES}

\section{A. Maintain/Enhance Habitat Values}

The major purpose of this land acquisition is to ensure the long-term protection and maintenance of the riparian/wetland values associated with the island. The island presently consists of a variety of riparian and wetland habitats typical of braided river system including gravel and sand bars, backwater channels, dense riparian shrub cover types, and young to mature cottonwood forests. The following description represents the key aquatic, wetland, and riparian habitats and general fish and known wildlife values associated with these habitat types..

\section{Aquatic Habitat Types}

The island shorelines provide a diversity of habitats from high-gradient gravelbottomed channels to mud-bottomed backwater sloughs. These habitats support a wide array of aquatic plants and animals which in turn provide habitat for resident and migratory juvenile and adult fish such as bull trout, west-slope cutthroat trout, pygmy and lake whitefish, rainbow trout, lake trout (mackinaw), northern pike, large-scale sucker, squawfish and peamouth. Western toads and painted turtles also use these aquatic habitat types. Shorebirds, waterfowl, raptors and other species which are commonly found foraging along the shoreline include great blue herons, solitary sandpipers, great cormorants, common mergansers, mallards, wood ducks, osprey, bald eagles, and kingfishers. Aquatic furbearing mammals dependent on backwater sloughs, log jams, riparian shrub and cottonwood forests and other wetlands include river otter, beaver, mink, and muskrat.

\section{Riparian Habitat Types}


The dense shrub cover along backwater sloughs and channels provides excellent upland nesting habitat for mallards, Canada geese, ruffed grouse, ring-necked pheasants, and wild turkey. The older cottonwood snags provide cavity nesting habitat for wood ducks, common and hooded mergansers, woodpeckers, tree swallows, and chickadees. Overhanging banks provide nesting habitat for belted kingfisher, bank swallows, and rough-winged swallows. Riparian shrubs and mature cottonwood habitats also provide nesting habitat for a variety of neo-tropical migrants and other passerines. The security and cover on the island provide important habitat for white-tailed deer.

The island's accumulated log jams, dead and down material, berry-producing shrubs such as hawthorn provide habitat for raccoons, striped skunks, coyotes, and red fox. Black bear and moose are occasional visitors.

\section{Proposed Actions}

a. FWP will complete an inventory and map of aquatic, wetland, and riparian habitats and their associated species and values during 1996. This baseline report will include photo points, vegetation lists, cover type maps, stand size and stocking, species lists, weed maps, human disturbances, and other data from which future changes in habitat quality can be detected. This baseline information will be critical to monitoring changes, adapting new management policies to address changes as needed to ensure maintenance of the existing habitat quality.

b. FWP will incorporate a weed management plan into the Coriell Island Management Plan during summer, 1996. This plan will address how FWP intends to meet county weed management obligations. The weed management plan will address the current infestation of Canada thistle and any other weeds observed during baseline inventories.

c. FWP will undertake at least 1 field inspection trip each year for purpose of monitoring habitat changes or impacts, updating resource values, and recommending management changes as needed. FWP will encourage local interest organizations to participate and assist on this field trip(s). The purpose of the field inspection is to insure long-term protection and maintenance of these riparian/wetland values, and compliance with this management plan, A record of field investigations will be kept with the management plan.

d. FWP will evaluate the benefits or detriments of including the Coriell project within the Montana Natural Areas Program.

\section{B. Maintaining Public Recreational Opportunities}

Maintaining recreation opportunities for the general public is an important but secondary objective of the Coriell land acquisition. Many islands in the mainstem Flathead are perceived as being in public ownership, although many are not. Purchase of Coriell by FWP will insure some degree of public access, provided access does not conflict with the habitat objectives stated above. 


\section{Current Recreation Activities}

Current recreation uses of Coriell, although a private island, seem to be similar to that which occurs on most islands in the mainstem Flathead which are in public ownership: boating; picnicking; fishing; day hiking; photography; asparagus picking; bird watching; camping; waterfowl, upland bird, and deer hunting; and furbearer trapping. Neither the Flathead Land Trust or Dr. Coriell have posted the island.

Most of these recreational activities which take place are passive, and occur either infrequently or seasonally, such as hunting. Based on preliminary observations, these activities seem to have had little impact on the islands's habitat quality. At present, there are at least two deer stands and a waterfowl blind on the island.

a. Spring: Intense or frequent recreation activities during the spring bird nesting/reproduction period (March through June) could impact nesting success of waterfowl and other wildlife species. Dogs allowed to run through the island can pose a significant hazard. However, because of the difficulty in negotiating the ever-changing channels near Coriell during spring with normal propeller motor boats, the lack of an easy access point adjacent, and rising treacherous water associated with spring runoff, public use during this time does not appear to be in conflict with nesting/reproducing wildlife. This could change with the increased use of jet boats and jet skis which can negotiate the shallow channels and can go up or down stream with few problems.

b. Summer: During summer, Flathead Lake is at full pool which allows normal propeller boats to reach Coriell from the south. Also, floating from Old Steel down to Foys Bend or Leisure Island is fairly common as the water levels stabilize and warm. The Flathead mainstem may warm even more than in the past due to the construction of the selective withdrawal system at Hungry Horse dam. Warmer water may increase recreational activities on the mainstem. Fishing, picnicking, hiking, bird watching, and camping, if it occurs frequently, could disrupt wildlife populations using the island or impact habitat.

c. Fall: The fall season includes upland bird, waterfowl, and big game hunting seasons. The island is one of the few places in the Flathead Valley which provides both wildlife habitat and defacto access for these recreational activities. The amount of hunting activity which takes place on Coriell is not presently known; however, several deer and duck blinds indicate it is used by the public, probably on most weekends during the hunting season. As with the other recreational activities, if it becomes too frequent, impacts to habitat or wildlife may occur.

d. Winter: Trapping rights have been previously reserved by a local trapper. Trapping primarily for beaver or river otter were likely to have occurred on Coriell during the winter months. Access to the island from Leisure island is dependent on water levels, ice cover, and motor boat type. Because of 
dropping water levels during the fall, safe access with regular propeller motor boats on a daily basis after November first is tricky. At least one active beaver lodge exists on the island.

Trapping rights have been recently cleared on the property's title. The braided section of the Flathead has had one of the highest beaver colony densities recorded in the state. Additionally, river otters are abundant throughout the Flathead mainstem probably due to habitat quality and high security; Montana allows trappers to take as many beaver as they want, but only one river otter.

\section{Recommended Actions:}

a. Limit certain recreational uses which will likely have an impact on wildlife during the spring nesting/reproductive period or leave excessive signs of human use:

i. no dogs/pets without leashes allowed from March 1 to June 30.

ii. put up signs which explain management objectives and ask the public to minimize human impacts (pack it in/pack it out; other restrictions listed below)

iii. No overnight camping; no fires; no permanent structures (e.g. duck blinds, deer stands, fire rings, tent poles etc.); temporary structures brought by an individual and removed by the individual after each hunt would be acceptable.

b. Provide copy of the final management plan to sporting good shops, County Offices and Library, local Chambers of Commerce, state and federal agencies, and interested publics to make them aware of management goals, objectives, and stipulations.

c. Coordinate management plan and monitoring with FWP enforcement staff, local interest groups, Flathead County Parks and Recreation.

\section{Monitoring and Adaptive Management:}

Most WHPA's receive little monitoring by FWP due to their small size, isolation, and lack of perceived need to monitor these areas because of low use. However, due to the proximity of Coriell to a large population center, the evidence of many recreational uses, and special wildlife values associated with the island, monitoring on a regular basis is recommended. This could be accomplished with volunteers and enforcement staff in addition to FWP resource personnel. The purpose of monitoring will be to determine if any recreational or human activities are impacting wildlife or habitat values.

a. Monitor recreation activities over the next 2 years to determine to what degree these activities take place, by whom, and with what frequency. 
b. Compile brief report of results of monitoring activities and any concerns and distribute to local interests, organizations, County Offices, and other interests.

c. Develop proposed management recommendations through public review process and modify management plan as needed. 
APPENDIX C

\section{CORIELL ISLAND}

\section{SOCIO-ECONOMIC ASSESSMENT}

Montana Fish, Wildlife and Parks

Prepared by:

Rob Brooks, FWP 


\section{INTRODUCTION}

House Bill 526 passed by the 1987 Legislature (MCA 87-1-241, MCA 87-1-242) authorizes the Montana Fish, Wildlife and Parks (MFWP) to acquire an interest in land for the purpose of protecting and improving wildlife habitat. Additionally, the Northwest Power Act authorized funds for acquiring wildlife habitat due to habitat losses from the development of Libby and Hungry Horse dams. These acquisitions can be through fee title, conservation easements, or leasing. In 1989, the Montana legislature passed House Bill 720 requiring that a socioeconomic assessment be completed when wildlife habitat is acquired. These assessments evaluate the significant social and economic impacts of the purchase on local governments, employment, schools, and impacts on local businesses.

This socioeconomic evaluation addresses the fee title purchase of land owned by the Flathead Land Trust. The report addresses the physical and institutional setting as well as the social and economic impacts associated with the proposed purchase.

\section{PHYSICAL AND INSTITUTIONAL SETTING}

\section{A. Property Description}

The property is an island in the Flathead River located just upstream from the confluence of the Stillwater River. The Coriell property comprises 73 acres of the eighty acre island. It does not appear the remaining acres are in private ownership. A legal description and map of the property are in the environmental assessment (EA).

\section{B. Habitat and Wildlife Populations}

Due to the braided nature of the Flathead River in this area, the islands in this section contain mature and old growth forest as well as excellent riparian habitat.

This land supports numerous game species (white-tailed deer, pheasants, turkey, waterfowl, grouse) as well as habitat for a long list of other wildlife. A detailed list is provided in Appendix A of the draft environmental assessment (EA) and management plan for the property.

\section{Current Use}

The property is currently owned by the Flathead Land Trust. They have managed the land to protect the wildlife and habitat values associated with the property. While the island is privately owned the Flathead Land Trust has allowed public access to the property for recreational uses.

\section{Management Alternatives}

At this point in time, two alternatives are available to the Montana Fish, Wildlife and Parks regarding the Coriell property.

1) Fee title purchase of the property by MFWP.

2) No purchase 
Other alternatives were considered in regards to protecting the property such as conservation easements and leasing. They are discussed in the environmental assessment (EA).

\section{Fee Title Purchase by MFWP}

Alternative 1, fee title purchase will provide protection to the land and wildlife of the Coriell property in the long term. The property will continue to be managed for the benefit of the wildlife. In addition, public access will be maintained. As stated in the EA, under MFWP ownership activities that might result in harm to the land or wildlife resources would not be allowed, such as sand and gravel removal, cottonwood logging, or cabin construction.

\section{No Purchase Alternative}

This alternative requires some assumptions since management of the property will vary depending on what the Flathead Land Trust (FLT) decides to do with the property if MFWP does not purchase the property. Flathead Land Trust focus is on protecting lands through conservation easements and education. They are not in the business of owning and managing land. In fact their policy is not to own land. If MFWP is unable to purchase this land, FLT is planning to sell to the land fee simple. There is no way to insure the new owners will protect the land and wildlife values this property has or that public access for recreational purposes will be allowed.

The economic impacts of the no purchase alternative have not been quantified here since they are unknown.

\section{SOCIAL AND ECONOMIC IMPACTS}

Section II identified the management alternatives this report addresses. Section III quantifies the social and economic consequences of the fee title purchase alternative following two basic accounting stances: financial and local area impacts.

Financial impacts address the cost of the fee title purchase to MFWP and discusses the impacts on tax revenues to local government agencies.

Expenditure data associated with the use of the property provides information for analyzing the impacts of the purchase on local businesses (i.e. income and employment).

\section{A. Financial Impacts}

The financial impacts on MFWP are related to the fee title purchase price and maintenance/management costs. The Coriell property will cost MFWP $\$ 22,000$.

This is substantially less that the appraised value of the property.

Maintenance/management costs related to the purchase are associated with the habitat monitoring anticipated for the land as well as weed control management plan. 
The financial impacts to local governments are the potential changes in tax revenues resulting from fee title purchase. Flathead Land Trust paid $\$ 638.00$ in taxes on this land in 1994. After receiving their tax exempt status they did not pay taxes on this property in 1995.

Montana Code Section 87-1-603 requires MFWP to pay the county "a sum equal to the amount of taxes which would be payable on county assessment of the property were it taxable to a private citizen". This payment in lieu of taxes provision on land owned by MFWP insures the Flathead County tax revenues from this land.

\section{B. Economic Impacts}

The purchase of this land by MFWP will not change the use of this land from what has occurred in the past. This land has not been used for commercial purposes in the past and these activities are not planned under MFWP ownership. This area has been used for recreational purposes (picnicking, camping, hunting, boating) and these will continue.

\section{FINDINGS AND CONCLUSIONS}

The Coriell property purchase will protect important wildlife habitat in the Flathead River and help mitigate habitat losses from Libby and Hungry Horse dams. Since this property is located close to other public lands in the river corridor, public recreation opportunities are enhanced and protected.

The fee title purchase will restore the property tax revenues from this land to local government entities in Flathead County. Tax revenues in 1994 on this property were $\$ 638.00$.

There are no significant economic impacts associated with the purchase.

The fee title purchase of the Coriell property appears to be in the public interest. 

